\title{
Somatostatin-Induced Changes in Insulin and Glucagon Secretion in Normal and Diabetic Dogs
}

\author{
Hideo Sakurat, Richard Dobbs, and Roger H. Unger \\ From the Veterans Administration Hospital, Dallas, Texas, and Department of \\ Internal Medicine, The University of Texas Southwestern Medical School at \\ Dallas 75235
}

A B S T R A C T In conscious dogs intravenously infused somatostatin ( $3.3 \mu \mathrm{g}$ per $\min$ for $1 \mathrm{~h}$ ) caused prompt and sustained declines in mean plasma insulin and glucagon, even during alanine infusion and intraduodenal casein hydrolysate feeding; plasma glucose declined, but not significantly. $6.7 \mu \mathrm{g}$ per min of somatostatin significantly lowered pancreatoduodenal vein glucagon and insulin within $2.5 \mathrm{~min}$ and profoundly suppressed their secretion throughout the infusion. Consistent bihormonal suppression occurred at rates as low as $24 \mathrm{ng}$ per $\mathrm{kg}$ per min, but was variable at 12 and $2.4 \mathrm{ng}$ per $\mathrm{kg}$ per min. When somatostatin-induced ( $3.3 \mu \mathrm{g}$ per min) hypoglucagonemia was corrected by exogenous glucagon, hyperglycemia occurred. In dogs with long-standing insulin-requiring alloxan diabetes $3.3 \mu \mathrm{g}$ per min of somatostatin suppressed glucagon to $55 \mathrm{pg}$ per $\mathrm{ml}$ throughout the $30-\mathrm{min}$ infusion and lowered glucose by $36.4 \pm 6.1 \mathrm{mg}$ per $\mathrm{dl}$, about $1 \mathrm{mg}$ per dl per min. Glucagon suppression was maintained despite alanine infusion, and glucose, which rose $29 \mathrm{mg}$ per dl during alanine infusion without somatostatin, declined $58 \mathrm{mg}$ per $\mathrm{dl}$ in the somatostatin-treated diabetic dogs despite alanine. Continuous infusion of somatostatin for $24 \mathrm{~h}$ in five insulin-requiring alloxan-diabetic dogs suppressed glucagon and lowered glucose significantly, usually to below normal.

It is concluded that in normal dogs pharmacologic doses of somatostatin virtually abolish insulin and glucagon secretion in the basal state and during hyperaminoacidemia. Hyperglycemia occurs during somatostatin-induced insulin lack only if hypoglucagonemia is corrected. Somatostatin suppresses glucagon in diabetic dogs and lowers their plasma glucose approximately 1 mg per dl per min, even when the gluconeogenic substrate alanine is abundant. Glucagon suppression can be

Presented at the annual meeting of the American Diabetes Association in Atlanta, Georgia, 16 June 1974.

Received for publication 12 June 1974 and in revised form 20 August 1974. maintained for several hours in such dogs and hyperglycemia is thereby reduced.

\section{INTRODUCTION}

It has recently been reported that the hypothalamic polypeptide somatostatin (1) is a potent inhibitor of insulin and glucagon secretion in humans, in baboons, and in the perfused dog pancreas (2-6). The present studies were designed to characterize further these responses and to assess their impact upon glucose homeostasis under varying circumstances of nutrient availability in nondiabetic dogs and in dogs with long-standing alloxan diabetes.

\section{METHODS}

Mongrel dogs, weighing between 19 and $27 \mathrm{~kg}$ were used in all experiments. Two or more days before an experiment, a catheter was inserted under Nembutal anesthesia through the jugular vein into the inferior vena cava and anchored in place. In some dogs, a small glass T-cannula connected with Teflon tubing was implanted into the superior pancreaticoduodenal vein at a distance of about $3 \mathrm{~cm}$ from its junction with the portal vein so as to permit direct sampling of pancreatic venous effluent. In another group of dogs, a polyethylene catheter was anchored with one end in the duodenal lumen so as to permit intraduodenal administration of casein hydrolysate.

In another series of experiments, dogs with alloxan diabetes of 18-29 mo duration and receiving from 22 to $35 \mathrm{U}$ of $\mathrm{NPH}$ insulin daily were employed. Their weights ranged from 21 to $26 \mathrm{~kg}$.

All dogs were studied after an overnight fast in a fully conscious state. In the acute experiments involving diabetic dogs, the 7 a.m. insulin dose was omitted on the day of the experiment, but $10-18 \mathrm{U}$ of $\mathrm{NPH}$ insulin was administered at 3 p.m. on the preceding day. Experiments were conducted between 9 and 12 a.m.

In 3-day continuous infusion experiments in diabetic dogs 6-10 U of NPH insulin was injected at 7 a.m. and 2:30 p.m., and the usual meal was given immediately after. No day-to-day variations in food intake occurred. The meal consisted of $215 \mathrm{~g}$ of carbohydrate, $93 \mathrm{~g}$ of protein, and $33 \mathrm{~g}$ of fat in the form of Purina Dog Chow (Ralston Purina Co., St. Louis, Mo.) supplemented with meat. Blood 


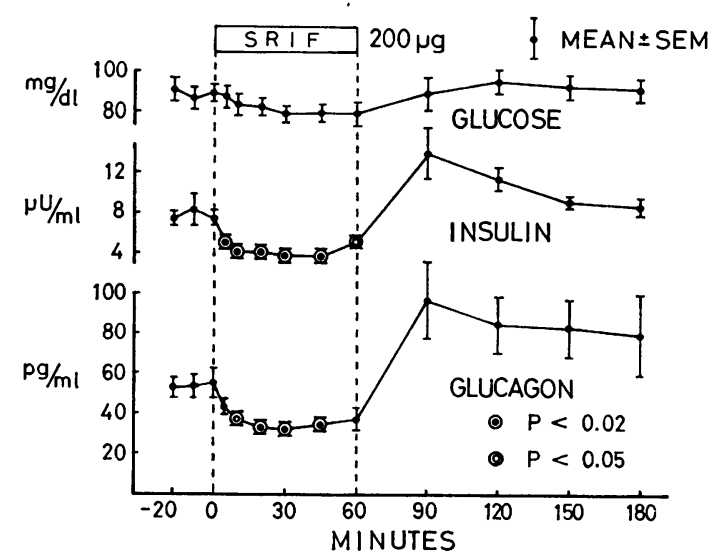

Figure 1 The effect of a 1-h somatostatin (SRIF) infusion (3.3 $\mu \mathrm{g}$ per $\mathrm{min}$ ) on glucose, insulin, and glucagon levels in peripheral venous plasma. $n=9$.

specimens were obtained at 7:00 and 9:00 a.m. and at $12: 00,2: 30$, and $4: 30$ p.m. by venipuncture.

Somatostatin $^{1}$ was administered in normal saline adjusted to $\mathrm{pH} 7.4$ through catheters implanted in a crural vein. In experiments in which alanine was employed, the amino acid was infused in a dose of $1 \mathrm{mmol}$ per $\mathrm{kg}$ of body wt over a 15-min period in a volume of $60 \mathrm{ml}$ of normal saline.

Blood specimens were collected in syringes rinsed with $10 \%$ solution of EDTA and transferred to tubes containing 500 kallikrein inhibitor units of Trasylol and $1.2 \mathrm{mg}$ of EDTA-2Na per $\mathrm{ml}$ of blood. Plasma was separated immediately and stored at $-20^{\circ} \mathrm{C}$ until the time of assay. Plasma glucose was determined by the glucose-oxidase method using the Technicon Autoanalyzer (Technicon Instruments Corp., Tarrytown, N. Y.). Insulin was measured by the radioimmunoassay of Yalow and Berson (7) as modified by Herbert, Lau, Gottlieb, and Bleicher (8), and pancreatic glucagon was assayed by the previously described radioimmunoassay (9), modified as follows: The system employed in assaying peripheral levels of glucagon included $7.5 \mathrm{pg}$ of $\left[{ }^{225} \mathrm{I}\right]$ glucagon, ${ }^{2} 1,000 \mathrm{U}$ of Trasylol, $0.5 \mathrm{ml}$ of plasma sample, and antiserum $30 \mathrm{~K}$ in a final dilution of 1 : 100,000 making a final volume of $1.2 \mathrm{ml}$ and had a sensitivity of approximately $20 \mathrm{pg}$ per $\mathrm{ml}$. Pancreaticoduodenal vein samples and specimens from diabetic dogs were assayed in a system with a sensitivity of approximately $35 \mathrm{pg}$ per ml employing $15 \mathrm{pg}$ of [ ${ }^{125} \mathrm{I}$ ] glucagon, $0.2 \mathrm{ml}$ of plasma, and $30 \mathrm{~K}$ in a 1:60,000 dilution, except when "zero" values were obtained, in which case they were reassayed in the more sensitive assay.

\section{RESULTS}

Effect of somatostatin on plasma insulin, glucagon, and glucose in normal fasting dogs. Somatostatin, infused in nine normal dogs at a constant rate of $3.3 \mu \mathrm{g}$

${ }^{1}$ Linear somatostatin, a gift of Dr. Roger Guillemin, Salk Institute, La Jolla, Calif., was employed in all experiments in nondiabetic dogs. Cyclic somatostatin, a gift of Dr. Romano DeGenghi, Ayerst Company, Montreal, Canada, was used in all experiments in diabetic dogs.

'Kindly provided by Miss A. M. Eisentraut, Nuclear Medical Laboratories, Dallas, Tex. per min for $1 \mathrm{~h}$, caused a decline in mean plasma insulin and glucagon within $5 \mathrm{~min}$, the first postinjection sample point (Fig. 1). Insulin fell from $7.6 \pm 0.8 \mu \mathrm{U}$ per $\mathrm{ml}$ to $5.1 \pm 0.5$ at $5 \mathrm{~min}(P<0.02)$ and to a nadir of $3.7 \pm 0.3$ at $45 \mathrm{~min}(P<0.001)$, rising to $14 \pm 2.5 \mu \mathrm{U}$ per $\mathrm{ml} 30$ $\min$ after the end of the infusion. Glucagon declined from $56 \pm 8 \mathrm{pg}$ per $\mathrm{ml}$ at zero time to $43 \pm 4$ at $5 \mathrm{~min}$ (N. S.) and reached a nadir of $32 \pm 2$ at $30 \mathrm{~min}(P<$ $0.01)$. When the infusion was discontinued glucagon rose sharply to $96 \pm 20 \mathrm{pg}$ per $\mathrm{ml}$. The mean molar ratio of insulin to glucagon, not shown in Fig. 1, did not change significantly from the mean basal value of $3.6 \pm$ 0.3 at any point during the infusion.

Mean plasma glucose declined slightly from $89.4 \pm 4.9$ $\mathrm{mg}$ per dl to a nadir of $78.9 \pm 3.6$ at $30 \mathrm{~min}$, but the changes in mean glucose concentration were not statistically significant.

Effects of somatostatin on pancreaticoduodenal vein insulin and glucagon. To determine whether or not the changes in islet hormone concentration observed in the peripheral plasma represent simultaneous or sequential secretory changes, five normal conscious dogs with indwelling pancreaticoduodenal vein catheters received somatostatin intravenously at a rate of $6.7 \mu \mathrm{g}$ per min for $30 \mathrm{~min}$, and samples were obtained at more frequent intervals (Fig. 2). The mean glucagon level declined from $246 \pm 24 \mathrm{pg}$ per $\mathrm{ml}$ to $123 \pm 32 \mathrm{pg}$ per ml at $1 \mathrm{~min}(P<0.02)$ and gave "zero" readings in the assay. When reassayed in the more sensitive system, a nadir of $32 \pm 14$ at $20 \mathrm{~min}$ was recorded $(P<0.001)$. A rebound well above the base-line values was observed after termination of the infusion. Although in two of the dogs insulin declined during the 1 st min, a statisti-

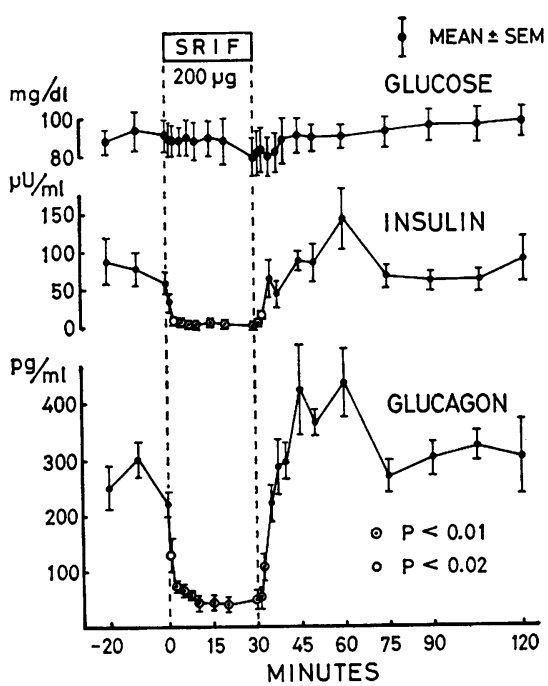

FIGURE 2 The effect of a 30-min somatostatin (SRIF) infusion (6.7 $\mu \mathrm{g}$ per min) on glucose, insulin, and glucagon levels in pancreaticoduodenal vein plasma. $n=5$. 
cally significant change in the mean insulin level first appeared $2.5 \mathrm{~min}$ after the start of the infusion $(P<$ $0.01)$. Suppression was maintained throughout the remainder of the infusion, the minimal mean insulin level being $2.1 \pm 0.9 \mu \mathrm{U}$ per $\mathrm{ml}$ at 20 and $30 \mathrm{~min}$. A rebound to or above basal levels followed the termination of the infusion and persisted for the ensuing $30 \mathrm{~min}$.

In three of the five dogs, glucagon secretion was suppressed before insulin, while in the other two the hormones declined simultaneously. Glucose declined from a zero time average of $91.0 \pm 8.9 \mathrm{mg}$ per $\mathrm{dl}$ to $80.0 \pm 11.5$ at the end of the infusion (N.S.).

The effect of somatostatin on plasma insulin, glucagon, and glucose during alanine infusion in normal dogs. Alanine is a gluconeogenic precursor (10) known to stimulate glucagon secretion (11). To determine if somatostatin alters the glucagon response to alanine the amino acid was infused at a rate of $1 \mathrm{mmol}$ per $\mathrm{kg}$ for $15 \mathrm{~min} 30 \mathrm{~min}$ after the start of a 1-h infusion of either somatostatin ( $3.3 \mu \mathrm{g}$ per $\mathrm{min}$ ) or a saline control (Fig. 3). In the control experiments insulin rose slightly and glucagon substantially, and plasma glucose increased from $90.0 \pm 5.2 \mathrm{mg}$ per dl to $103.0 \pm 3.7$. In dogs receiving somatostatin both insulin and glucagon levels remained suppressed during the alanine infusion. The mean glucose level in the somatostatin-treated group was significantly below the controls during the alanine infusion and immediately thereafter $(P<0.01)$ by the $t$ test for two groups.

Effect of somatostatin on the insulin and glucagon responses to intraduodenal casein hydrolysate. The in-

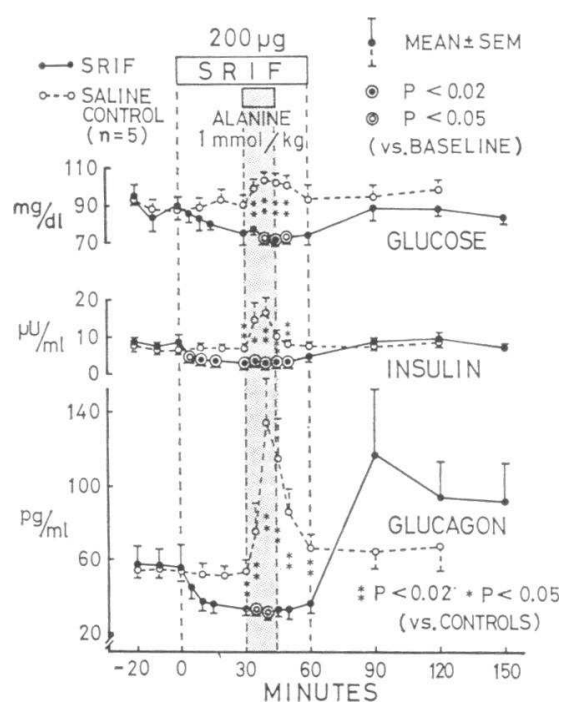

FIGURE 3 The effect of a 1-h somatostatin (SRIF) infusion ( $3.3 \mu \mathrm{g}$ per $\mathrm{min}$ ) or a saline control infusion on the glucose, insulin, and glucagon levels in peripheral plasma during a 15-min intravenous infusion of $1 \mathrm{mmol}$ per $\mathrm{kg}$ of alanine. $n=6$.

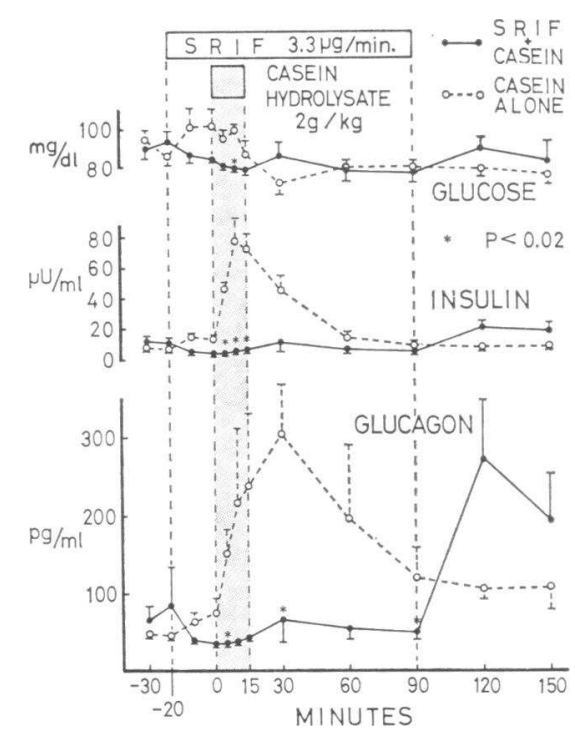

FIGURE 4 The effect of somatostatin (SRIF) infusion (3.3 $\mu \mathrm{g}$ per min) or a saline control infusion on the glucose, insulin, and glucagon levels in peripheral plasma after the intraduodenal instillation of casein hydrolysate $(2 \mathrm{~g}$ per $\mathrm{kg}) . n=4$.

gestion of protein or amino acids is normally associated with a rise in plasma insulin and glucagon (12-14). To determine if somatostatin interferes with this response, a group of four conscious dogs were given $2 \mathrm{~g}$ per $\mathrm{kg}$ of casein hydrolysate via an intraduodenal catheter during the intravenous infusion of either $3.3 \mu \mathrm{g}$ per min of somatostatin or a saline control in paired experiments carried out in random order. As shown in Fig. 4, somatostatin virtually abolished the rises in insulin and glucagon observed with casein alone. A brisk rebound of both hormones followed discontinuation of the somatostatin infusion. A statistically significant difference in glucose was observed only at $10 \mathrm{~min}$ after the casein meal when glucose averaged $100.0 \pm 2.0 \mathrm{mg}$ per $\mathrm{dl}$ in the controls and $80.0 \pm 2.0$ in the somatostatinized group.

Effects of low doses of somatostatin on insulin, glucagon, and glucose. Because the foregoing doses of somatostatin are almost certainly pharmacologic, an attempt was made to determine the minimum dose of somatostatin that suppresses insulin and/or glucagon secretion. The peptide was infused in a group of normal dogs at rates of 2.4, 12 and $24 \mathrm{ng}$ per $\mathrm{kg}$ per min for $20 \mathrm{~min}$, and blood specimens were obtained from the pancreaticoduodenal vein at $2.5,5,10,15$, and $20 \mathrm{~min}$ after the start of the infusion. The results are summarized in Table I. A sustained suppression of both hormones was observed at the $24 \mathrm{ng}$ per $\mathrm{kg}$ per min rate in all three dogs, but was not statistically significant because of the small sample size. At both of the lower rates, the responses were less consistent and more transient and not statistically significant. 
TABLE I

Pancreaticoduodenal Vein Insulin and Glucagon Levels at Various Rates of Somatostatin Infusion for 20 min (Mean $\pm S E M$ )

\begin{tabular}{|c|c|c|c|c|c|c|}
\hline & \multicolumn{2}{|c|}{$\begin{array}{c}2.4 \mathrm{ng} / \mathrm{kg} / \mathrm{min} \\
(n=4)\end{array}$} & \multicolumn{2}{|c|}{$\begin{array}{c}12 \mathrm{ng} / \mathrm{kg} / \mathrm{min} \\
(n=4)\end{array}$} & \multicolumn{2}{|c|}{$\begin{array}{c}24 \mathrm{ng} / \mathrm{kg} / \mathrm{min} \\
(n=3)\end{array}$} \\
\hline & $\begin{array}{l}\text { Mean of } \\
\text { baseline }\end{array}$ & $\begin{array}{l}\text { Mean of the } \\
\text { minimal levels }\end{array}$ & $\begin{array}{l}\text { Mean of } \\
\text { baseline }\end{array}$ & $\begin{array}{l}\text { Mean of the } \\
\text { minimal levels }\end{array}$ & $\begin{array}{l}\text { Mean of } \\
\text { baseline }\end{array}$ & $\begin{array}{l}\text { Mean of the } \\
\text { minimal levels }\end{array}$ \\
\hline $\begin{array}{l}\text { Insulin, } \mu U / m l \\
\text { Glucagon, } p g / m l\end{array}$ & $\begin{array}{l}50.5 \pm 21.7 \\
134 \pm 25\end{array}$ & $\begin{array}{c}19.5 \pm 3.5 \\
114 \pm 12\end{array}$ & $\begin{array}{c}63.7 \pm 34.2 \\
209 \pm 68\end{array}$ & $\begin{array}{c}20.5 \pm 6.7 \\
138 \pm 42\end{array}$ & $\begin{array}{c}45.9 \pm 25.8 \\
187 \pm 65\end{array}$ & $\begin{array}{c}19.7 \pm 13.2 \\
105 \pm 35\end{array}$ \\
\hline
\end{tabular}

The effect of exogenous glucagon during somatostatin infusion. When insulin is suppressed by mannoheptulose (15) or diazoxide $(15,16)$ or neutralized with antiinsulin serum (15), both blood glucose and plasma glucagon rise. The absence of hyperglycemia during somatostatin-induced insulin suppression is, therefore, a unique finding, as is the absence of hyperglucagonemia. To examine the possibility of a causal relationship between these two unusual findings, the plasma glucagon levels during somatostatin-induced insulin suppression were raised by infusing $10 \mathrm{ng}$ per $\mathrm{kg}$ per min of crystalline glucagon together with $3.3 \mu \mathrm{g}$ per min of somatostatin for $60 \mathrm{~min}$ in a group of four dogs (Fig. 5). The mean glucagon concentration rose and was maintained above $200 \mathrm{pg}$ per $\mathrm{ml}$ throughout the somatostatin infusion, probably somewhat below the portal vein levels of glucagon occurring in other forms of experimental insulin deficiency; nevertheless, plasma glucose rose in every dog to a peak averaging $134 \mathrm{mg}$ per $\mathrm{dl}$ at $30 \mathrm{~min}$.

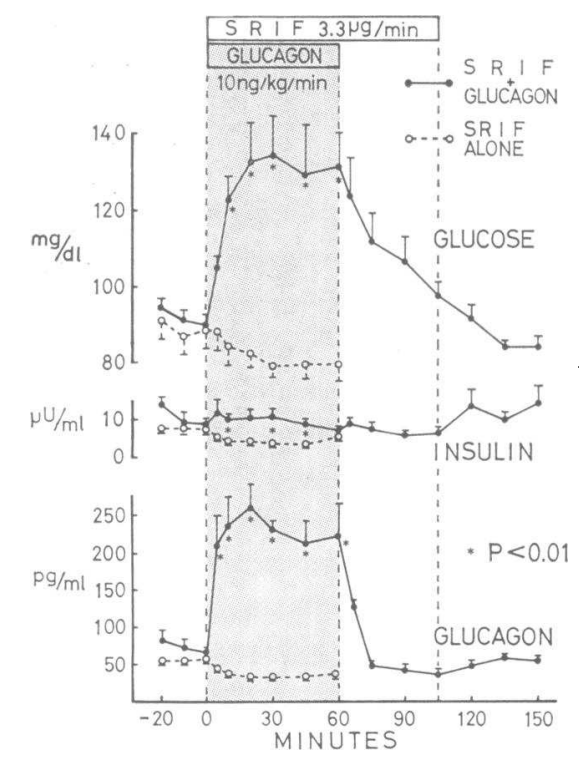

FIGURE 5 The effect of exogenous glucagon (10 ng per $\mathrm{kg}$ per min) on plasma glucose concentration during the suppression of insulin and glucagon induced by the infusion of somatostatin (SRIF) (3.3 $\mu \mathrm{g}$ per $\mathrm{min}) . n=4$.
The mean glucose level at every point was significantly greater than in dogs receiving the same dose of somatostatin without glucagon, the maximum difference in mean glucose levels between groups being $55 \mathrm{mg}$ per $\mathrm{dl}$. This difference is all the more notable when one considers that insulin was not suppressed by somatostatin during glucagon infusion (Fig. 5). When glucagon was discontinued, the continued infusion of somatostatin was accompanied by a decline in mean glucagon of almost 200 pg per $\mathrm{ml}$ during the ensuing $45 \mathrm{~min}$ and mean glucose fell $33 \mathrm{mg}$ per dl during this period, about $0.7 \mathrm{mg}$ per dl per min.

At a higher infusion rate of somatostatin, $6.7 \mu \mathrm{g}$ per min, the same dose of glucagon caused hyperglycemia averaging $155 \pm 5 \mathrm{mg}$ per $\mathrm{dl}$ at $20 \mathrm{~min}$.

Effects of somatostatin in diabetic dogs. To determine if glucagon suppression favorably influences glucose regulation in diabetes, the effect of somatostatin was studied in five dogs with long-standing alloxan diabetes. In random order 2 wk apart the dogs received a 30 -min intravenous infusion of either somatostatin ( $3.3 \mu \mathrm{g}$ per $\mathrm{min}$ ) or a saline control (Fig. 6). In the dogs receiving somatostatin glucagon declined from a mean of $114 \pm 14 \mathrm{pg}$ per $\mathrm{ml}$ at zero time to $80 \pm 10$ in $5 \mathrm{~min}$ and reached a nadir of $55 \pm 9$ at $20 \mathrm{~min}(P<$ $0.02)$. Glucose declined from a preinfusion average of

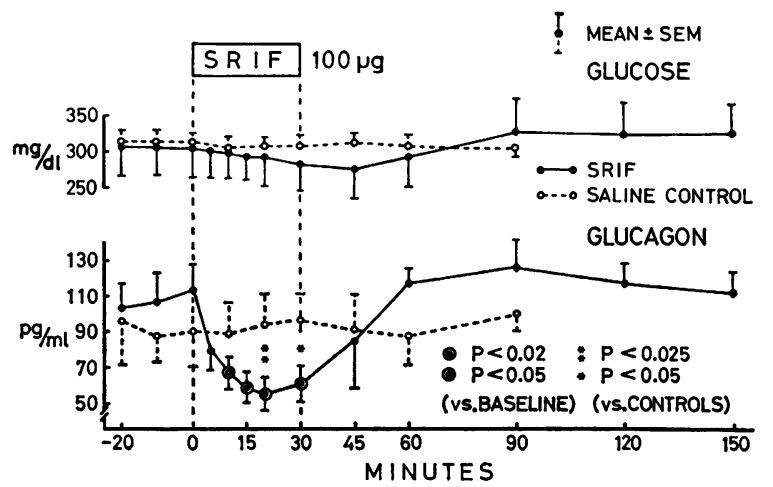

FIGURE 6 The effect of a 30-min somatostatin (SRIF) infusion (3.3 $\mu \mathrm{g}$ per min) or a saline control infusion on glucose and glucagon levels in dogs with long-standing alloxan diabetes. $n=5$. 


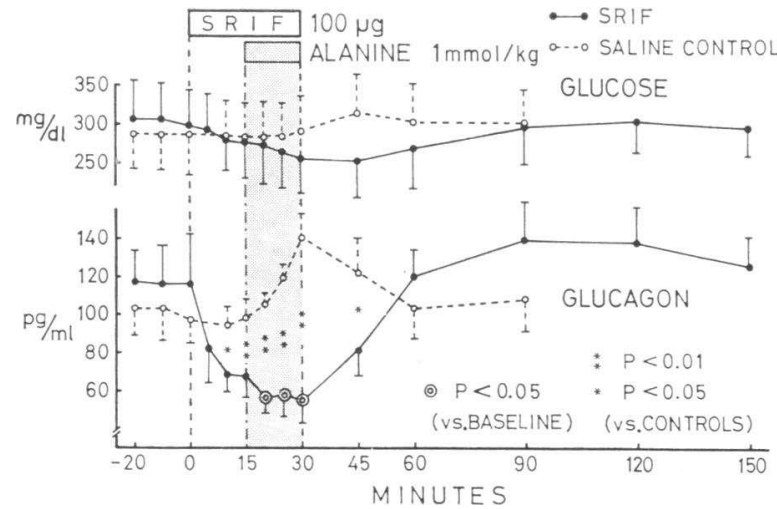

FIGURE 7 The effect of a 30 -min somatostatin (SRIF) infusion (3.3 $\mu \mathrm{g}$ per min) or a saline control infusion on glucose and glucagon levels during a 15-min intravenous infusion of $1 \mathrm{mmol}$ per $\mathrm{kg}$ alanine in alloxan-diabetic dogs. $n=5$.

$304.0 \pm 39.7 \mathrm{mg}$ per dl to a low of $275.0 \pm 38.4$ at $45 \mathrm{~min}$. Although the mean glucose levels during the somatostatin infusion did not differ significantly from the base- line values at any point, the maximal decline in glucose during the $45 \mathrm{~min}$ after the start of the infusion averaged $36.4 \pm 6.1 \mathrm{mg}$ per $\mathrm{dl}$, significantly greater by paired $t$ test than during the control infusion $(P<0.05)$.

To evaluate the effects of somatostatin on the responses to alanine in diabetes, five alloxan-diabetic dogs received alanine $(1 \mathrm{mmol}$ per $\mathrm{kg}$ ) during the last $15 \mathrm{~min}$ of a $30-\mathrm{min}$ infusion of somatostatin $(3.3 \mu \mathrm{g}$ per min) or of a saline control (Fig. 7). In the control studies, the infusion of alanine was accompanied by a rise in glucagon from $98 \pm 11 \mathrm{pg}$ per $\mathrm{ml}$ to a peak of $140 \pm 12$. During somatostatin infusion glucagon remained suppressed, averaging $55 \pm 13 \mathrm{pg}$ per $\mathrm{ml}$ at the end of the alanine infusion, significantly less than in the controls at 15,20,25, and $30 \mathrm{~min}(P<0.01)$, and 45 $\min (P<0.025)$. During alanine infusion in the controls glucose rose from $280 \pm 45$ to $313 \pm 50$, but during alanine infusion in the somatostatinized group it declined from a mean of $297.0 \pm 47.0 \mathrm{mg}$ per dl to a nadir of 252.0 \pm 48.8 . Although the mean glucose values in the two groups did not differ significantly, a paired comparison of glucose change from baseline revealed significant

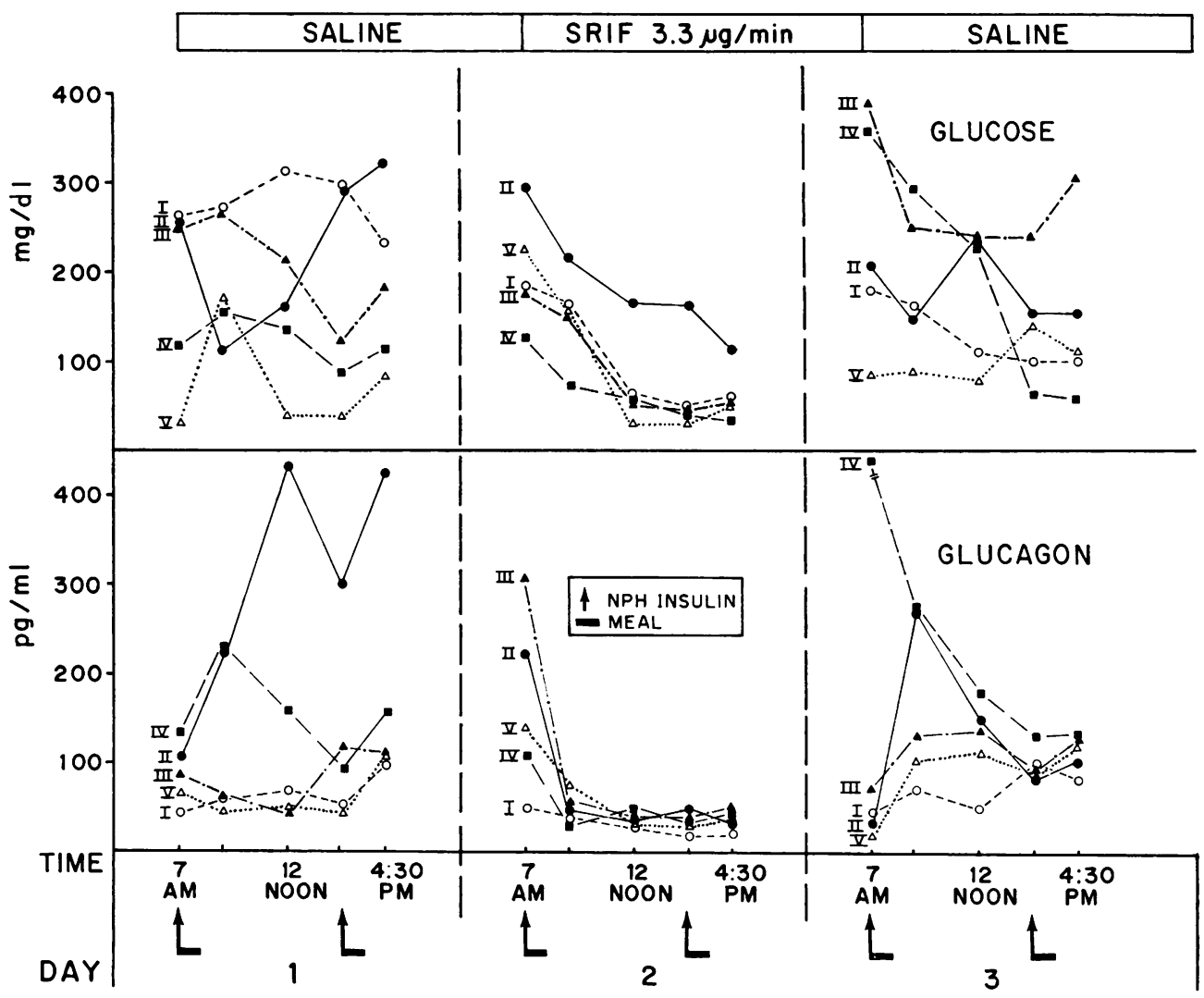

FIGURE 8 The effect of a 24-h intravenous infusion of somatostatin on the individual glucagon and glucose levels in five alloxan-diabetes dogs. Somatostatin was discontinued $10 \mathrm{~min}$ before obtaining the 7 a.m. sample on day 3 , except in dog IV in which the somatostatin infusion had been inadvertently interrupted sometime after $4: 30$ p.m. on day 2 . 
differences at $25,30(P<0.02), 45(P<0.05)$, and $60 \min (P<0.02)$.

To evaluate the effects of more prolonged glucagon suppression upon diabetic hyperglycemia, somatostatin was infused at a rate of $3.3 \mu \mathrm{g}$ in $0.3 \mathrm{ml}$ of saline per min for $24 \mathrm{~h}$ in five dogs with insulin-requiring alloxan diabetes. Saline alone was infused as a control at the same rate during the preceding and the subsequent $24 \mathrm{~h}$. Blood samples were obtained at the same time five times daily. The dogs received their usual insulin dose and their customary meal at 7 a.m. and 2:30 p.m. daily.

The individual results are shown in Fig. 8. Glucagon averaged $167 \mathrm{pg}$ per $\mathrm{ml}$ at the start of the somatostatin infusion at 7 a.m. By 9 a.m. it had declined to $75 \mathrm{pg}$ per $\mathrm{ml}$ or less in every dog. At noon it ranged between 25 and $50 \mathrm{pg}$ per $\mathrm{ml}$, significantly below the 7 a.m. value and close to the sensitivity limits of the glucagon assay. All glucagon values during the somatostatin infusion were significantly less by paired $t$ test than the corresponding levels at the same time on either the preceding or following day $(P<0.005)$.

Glucose levels, which averaged $214 \mathrm{mg}$ per $\mathrm{dl}$ before the somatostatin infusion at 7 a.m., also declined in every dog after the fall in glucagon. At noon the glucose was below $100 \mathrm{mg}$ per $\mathrm{dl}$ in four of the five dogs and remained below normal through 4:30 p.m. The glucose values during somatostatin infusion differed significantly by paired $t$ test from the corresponding values on each of the preceding control days of saline infusion $(P<0.01)$. A significant correlation between the glucagon and glucose levels was observed during the day of somatostatin therapy $(r=0.57, P<0.01)$. The uniform pattern of a declining glucagon level followed by a reduction in plasma glucose was in contrast to the irregular lability observed on the previous and subsequent days (Fig. 8).

\section{DISCUSSION}

These studies in conscious dogs confirm earlier reports (2-6) that the somatotropin release inhibiting factor (1) also inhibits the release of insulin and glucagon. They demonstrate that this blockade is not diminished by the infusion of alanine or by the feeding of a protein hydrolysate, that the glucagon-suppressing action is present in alloxan-diabetic dogs, even during the infusion of the gluconeogenic substrate, alanine, and that prolonged glucagon suppression is associated with a striking decrease in plasma glucose. The fact that the levels of both pancreatic hormones in the pancreaticoduodenal venous effluent declined to virtually unmeasurable values within 1-2.5 min of the start of a somatostatin infusion suggests an immediate block in their release, and the brisk rebound within $5 \mathrm{~min}$ after termination of the somatostatin infusion suggests an outpouring of previously blocked secretory products.
Somatostatin is unique in at least three respects. First, it is the most effective alpha cell suppressant yet discovered. Secretin has comparable glucagon-lowering activity only in the presence of hyperglycemia (17) and, while it reduces the glucagon response to alanine, it does not block it (18). Second, somatostatin is the only substance known to inhibit simultaneously the secretion of both insulin and glucagon; other insulin suppressants such as mannoheptulose and diazoxide are associated with an absolute or relative hyperglucagonemia (15, 16). Third, somatostatin can block insulin secretion for as long as an hour without causing hyperglycemia. In the dog, the plasma glucose level declines slightly, both in the fasting state and during alanine administration, but not to the degree observed in fasting baboons (6) and humans (2). Barring a direct insulinlike effect of somatostatin on hepatic glucose balance or upon glucose utilization by peripheral tissues, or a glucose lowering effect of growth hormone suppression, all of which seem unlikely $(6,19)$, a causal relationship between the lack of hyperglycemia and the lack of glucagon is plausible. In the present studies, which support this premise, the infusion of exogenous glucagon together with somatostatin raised mean plasma glucagon to between 200 and $260 \mathrm{pg}$ per ml. This is within the range of portal glucagon concentration in the basal state, but probably well below the portal vein levels in acute insulin deficiency of comparable severity (15) ; nevertheless, with glucagon present, plasma glucose levels increased by 28 to $73 \mathrm{mg}$ per dl above the basal values. Similar findings in baboons (20) provide strong evidence that glucagon makes a contribution to glucose homeostasis, which on the basis of all data available in these studies, approximates $1 \mathrm{mg}$ per dl per minute in the dog. If the decrease in glucose production resulting from the lack of glucagon were slightly greater than the decrease in glucose utilization resulting from the lack of insulin, the small decline in glucose concentration during somatostatin suppression would be explained.

Koerker et al. (6) calculate that in the baboon somatostatin infusion is accompanied by complete inhibition of hepatic glucose production. Simultaneous reduction in insulin and glucagon must decrease glucose turnover, just as simultaneous stimulation of the two hormones by arginine has been shown to increase glucose turnover as much as $70 \%$ above the basal (21). Yet glucose concentration changes relatively little in these contrasting circumstances, suggesting that glucagonmediated input into and insulin-mediated outflow from the glucose pool must be similar.

These studies provide new insight into glucagon's contribution to the hyperglycemia of diabetes. In the acute experiments in alloxan-diabetic dogs glucagon 
was suppressed by somatostatin to almost half of the basal levels in $30 \mathrm{~min}$. The associated mean maximal glucose decline during those $30 \mathrm{~min}$ averaged $33 \mathrm{mg}$ per $\mathrm{dl}$, or about $1 \mathrm{mg}$ per dl per min. And when glucagon returned to basal levels after termination of the infusion, the mean maximal rise in glucose from the nadir averaged $60 \mathrm{mg}$ per $\mathrm{dl}$ during the ensuing hour, again about $1 \mathrm{mg}$ per dl per min. Inasmuch as insulin could not have changed in these insulin-deficient dogs, the glucose changes may reflect the glucagon-mediated contribution to the hyperglycemia. Moreover, somatostatin prevented the alanine-induced rise in glucagon and maintained glucagon suppression at half basal levels. Instead of a $29 \mathrm{mg}$ per $\mathrm{dl}$ mean maximal rise in glucose during alanine infusion, a mean maximal decline of $58 \mathrm{mg}$ per dl was observed. The ability to suppress glucagon during hyperaminoacidemia may provide for the first time a means of correcting the paradoxical lowering of insulin-glucagon ratio caused by food (14) and amino acids (22) in severe diabetes without the need for additional meal-time insulin administration.

The 24-h somatostatin infusion experiments indicate that profound glucagon suppression can be uniformly maintained for at least $7.5 \mathrm{~h}$ in alloxan-diabetic dogs and that in most instances it reduced previously elevated and labile plasma glucose levels to a low normal range and, at least for the brief period of observation, seemed to maintain them there. A relationship between glucagon levels and glucose levels in diabetics with fixed insulin levels is suggested by the data. The pattern observed here, although limited to a single day, suggests that glucose levels are less labile when glucagon secretion is blocked and that sustained euglycemia, so difficult to achieve with insulin alone, may be possible if glucagon is concomitantly suppressed.

It remains to be determined if endogenous somatostatin is a physiologic regulator of the endocrine pancreas. LeBlanc, Anderson, Riggs, and Yen have shown that a single injection of $1 \mu \mathrm{g}$ can suppress glucagon and insulin in humans (23). If, in fact, somatostatin is a physiologic inhibitor of growth hormone, thyroidstimulating hormone, insulin, and glucagon secretion, a role as a reducer of metabolic turnover rates can be envisioned.

\section{ACKNOWLEDGMENTS}

The authors acknowledge the excellent technical assistance of Virginia Harris, Shirley Harvey, Kay McCorkle, Margaret Bickham, Catherine Mitchell, and Daniel Sandlin. They acknowledge with gratitude the help of Dr. Roger Guillemin.

This work was supported by National Institutes of Health grant Am 02700-15; The Upjohn Company, Kalamazoo, Mich.; Pfizer Laboratories, New York; Lilly Research
Laboratories, Indianapolis, Ind.; and CIBA-GEIGY Pharmaceuticals, Summit, N. J.

\section{REFERENCES}

1. Brazeau, P., W. Vale, R. Burgus, N. Ling, M. Butcher, J. Rivier, and R. Guillemin. 1973. Hypothalamic polypeptide that inhibits the secretion of immunoreactive growth hormone. Science (Wash. D. C.). 179: 77-79.

2. Mortimer, C. H., W. M. G. Turnbridge, D. Carr, L. Yeomans, T. Lind, D. H. Coy, S. R. Bloom, A. Kastin, C. N. Mallinson, G. M. Besser, A. V. Schally, and R. Hall. 1974. Effects of growth-hormone releaseinhibiting hormone on circulating glucagon, insulin, and growth hormone in normal, diabetic, acromegalic, and hypopituitary patients. Lancet. 1: 697-701.

3. Alberti, K. G., N. J. Christensen, S. E. Christensen, A. P. Hansen, J. Iversen, K. Lundbaek, K. SeyerHansen, and H. Ørskov. 1973. Inhibition of insulin secretion by somatostatin. Lancet. 2: 1299-1301.

4. Yen, S. S. C., T. M. Siler, and G. W. DeVane. 1974. Effect of somatostatin in patients with acromegaly. Suppression of growth hormone, prolactin, insulin, and glucose levels. N. Engl. J. Med. 290: 935-938.

5. Iversen, J. 1974. Inhibition of pancreatic glucagon release by somatostatin: In vitro. Scand. J. Clin. Lab. Invest. 33: 125-129.

6. Koerker, D. J., W. Ruch, E. Chideckel, J. Palmer, C. J. Goodner, J. Ensinck, and C. C. Gale. 1974. Somatostatin: hypothalamic inhibitor of the endocrine pancreas. Science (Wash. D. C.). 184: 482-483.

7. Yalow, R. S., and S. A. Berson. 1960. Immunoassay of endogenous plasma insulin in man. J. Clin. Invest. 39: $1157-1175$

8. Herbert, V., K. S. Lau, C. W. Gottlieb, and S. J. Bleicher. 1965. Coated charcoal immunoassay of insulin. J. Clin. Endocrinol. Metab. 25: 1375-1384.

9. Faloona, G. R., and R. H. Unger. 1974. Glucagon. In Methods of Hormone Radioimmunoassay. B. M. Jaffe and H. R. Behrman, editors. Academic Press, Inc., New York. 317-330.

10. Felig, P., T. Pozefsky, E. Marliss, and G. F. Cahill, Jr. 1970. Alanine: key role in gluconeogenesis. Science (Wash. D. C.). 167: 1003-1004.

11. Müller, W. A., G. R. Faloona, and R. H. Unger. 1971. The effect of alanine on glucagon secretion. J. Clin. Invest. 50: 2215-2218.

12. Fajans, S. S., J. C. Floyd, Jr., R. F. Knopf, and J. W. Conn. 1967. Effect of amino acids and proteins on insulin secretion in man. Rec. Prog. Horm. Res. 23: 617662.

13. Ohneda, A., E. Aguilar-Parada, A. M. Eisentraut, and R. H. Unger. 1968. Characterization of response of circulating glucagon to intraduodenal and intravenous administration of amino acids. J. Clin. Invest. 47: 23052322.

14. Müller, W. A., G. R. Faloona, E. Aguilar-Parada, and R. H. Unger. 1970. Abnormal alpha-cell function in diabetes: response to carbohydrate and protein ingestion. N. Engl. J. Med. 283: 109-115.

15. Müller, W. A., G. R. Faloona, and R. H. Unger. 1971. The effect of experimental insulin deficiency on glucagon secretion. J. Clin. Invest. 50: 1992-1999.

16. Samols, E., J. M. Tyler, and H. Kajinuma. 1971. Influence of the sulfonamides on pancreatic humoral secretion and evidence for an insulin-glucagon feedback system. In Proceedings of the Seventh Congress 
of the International Diabetes Federation. R. R. Rodriguez and J. Vallance-Owen, editors. Excerpta Medica, Amsterdam. 635-655.

17. Santeusanio, F., G. R. Faloona, and R. H. Unger. 1972. Suppressive effect of secretin upon pancreatic alpha cell function. J. Clin. Invest. 51 : 1743-1749.

18. Santeusanio, F., G. R. Faloona, and R. H. Unger. 1973. Inhibition of alanine-stimulated glucagon secretion in the dog. Horm. Metab. Res. 5: 425-427.

19. Gerich, J., M. V. Lorenzi, V. Scheider, J. Karan, J. Rivier, R. Guillemin, and P. Forsham. 1974. Effects of somatostatin on plasma glucose and glucagon levels in human diabetes mellitus. N. Engl. J. Med. 291: 544-547.

20. Goodner, C. J., J. W. Ensinck, E. Chideckel, J. Palmer,
D. J. Koerker, W. Ruch, and C. Gale. 1974. Somatostatin, a hypothalamic inhibitor of the endocrine pancreas. J. Clin. Invest. 53: 28 a. (Abstr.)

21. Cherrington, A. D., and M. Vranic. 1973. Effect of arginine on glucose turnover and free fatty acids in normal dogs. Diabetes. 22 : 537-543.

22. Unger, R. H., E. Aguilar-Parada, W. A. Muller, and A. M. Eisentraut. 1970. Studies of pancreatic alpha cell function in normal and diabetic subjects. J. Clin. Invest. 49: 837-848.

23. LeBlanc, H., J. Anderson, L. Riggs, and S. S. C. Yen. 1974. Characterization of the biological activities of somatostatin in humans. Endocrinology. 94: A157. (Abstr.) 